\title{
Renal and liver functions and muscle injuries during training and after competition in Thai boxers
}

Vitoon Saengsirisuwan, Supaporn Phadungkij, Chumpol Pholpramool

\begin{abstract}
Objective-To observe whether there are any injuries to muscle and deleterious effects on the liver and kidneys during training and after competition in Thai boxers.

Methods-Serum levels of intracellular enzymes and specific markers in the urine were measured during training and after fighting in Thai boxers.

Results-During the training period, the activities of muscle enzymes were significantly increased whereas those of the liver enzymes and creatinine clearance were not changed. After a match, on the other hand, both liver and muscle enzyme activities were elevated but renal function was decreased.

Conclusions-The training protocol for Thai boxers has virtually no deleterious effect on liver and renal function, but damage to skeletal muscle cells may occur. However, competition may cause muscle injury without any obvious damage to the liver and kidneys.

(Br F Sports Med 1998;32:304-308)
\end{abstract}

Keywords: Thai boxing; training; competition; liver; kidney; muscle

It is well established that deliberate or accidental trauma to tissues can lead to abnormal enzyme activity in the plasma. Physical exercise, particularly if strenuous or prolonged, has been shown to affect enzyme activities. ${ }^{1}$ Several studies have looked at the changes in urine and serum enzyme concentrations after exercise and sports activity. For example, after ultra long distance running, the activities of plasma aspartate and alanine aminotransferases (AST and ALT) were found to be elevated up to 5-fold and 3-fold respectively, ${ }^{2}$ and increases in serum creatine kinase (CK) and lactate dehydrogenase $(\mathrm{LDH})$ activities have been found after muscular exertion. ${ }^{3}{ }^{4}$ After moderate and

Department of Physiology, Faculty of Science, Mahidol University, Rama VI Road, Bangkok 10400, Thailand

V Saengsirisuwan

S Phadungkij

C Pholpramool

Correspondence to: Dr C Pholpramool.

Accepted for publication 4 March 1998 ing, hitting with the elbow, punching, kicking, knee throwing, tripping, etc. Injuries may also occur during the training period since the protocols also include dual fighting with either trainers or companions. Consequently, the risk of injury in Thai boxing is probably higher than in other sports. In an effort to reduce the injuries inherent in boxing, previous studies have focused attention mainly on neurological damage..$^{10}$ Besides the problem of brain trauma, damage to other organs also requires consideration. In this study, injuries to liver, muscle and kidney during training and after competition in Thai boxers were evaluated by determining serum enzyme activities and urine excretion of specific markers to assess the function of these organs.

\section{Methods}

SUBJECTS

Twenty male adolescents aged 14 to 17 years were enrolled in the study. The subjects were divided into two groups: controls and boxers. The control subjects consisted of ten sedentary youths who did not play any sports regularly; the boxers were ten young professional Thai boxers, from the Sor-Phloenchit boxing stable, who had competed in boxing matches for at least two years, with the frequency of fights ranging from 10 to 12 per year. Only boxers who had not competed for three weeks were included in the study. None of the participants had any indication of musculoskeletal disorders or abnormality of liver or renal function. Written informed consent consistent with the Mahidol University policy for the protection of human subjects was obtained from all volunteers.

PHYSICAL CHARACTERISTICS AND PERFORMANCE TEST

After the personal background, general health status, medical history, daily activity, and boxing history of each subject had been recorded, vital signs at rest, body weight and height, and percentage body fat using Siri's methods ${ }^{11}$ were measured in all subjects. Isometric muscle strength of the hand and leg were determined by using a hand grip and leg dynamometer. Maximum oxygen uptake of each subject was obtained by a direct gas analysis procedure. Briefly, the subject exercised on a bicycle ergometer equipped with an electromagnetic brake (Excalibur Sport, Lode, The Netherlands) using a progressive-load exercise test protocol. The work load was increased in a stepwise manner at $30 \mathrm{~W}$ every two minutes
During a match, all parts of the body may be used in attack and defence in the form of butt- 
Table 1 Physical data for the subjects (10 sedentary controls and 10 boxers). Values represent mean (SEM)

\begin{tabular}{|c|c|c|c|c|c|c|}
\hline & \multirow[b]{2}{*}{ Controls (SD) } & \multicolumn{2}{|l|}{ Boxers } & \multicolumn{2}{|c|}{ ANOVA ( $p$ value) } & \multirow[b]{2}{*}{ Paired t test NT $v$ IT } \\
\hline & & Normal training (NT) & Intensive training (IT) & $S D v N T$ & $S D v I T$ & \\
\hline Age (years) & $15.4(0.2)$ & $15.5(0.5)$ & & NS & NS & - \\
\hline Height $(\mathrm{cm})$ & $161.8(1.7)$ & $149.9(2.0)$ & & $<0.05$ & $<0.05$ & - \\
\hline Weight $(\mathrm{kg})$ & $52.0(2.3)$ & $40.0(2.1)$ & $40.8(1.9)$ & $<0.05$ & $<0.05$ & NS \\
\hline Body fat $(\%)$ & $15.2(1.7)$ & $8.6(0.6)$ & $8.5(0.3)$ & $<0.05$ & $<0.05$ & NS \\
\hline Lean body mass $(\mathrm{kg})$ & $43.8(1.1)$ & $36.5(1.8)$ & $37.3(1.7)$ & $<0.05$ & $<0.05$ & NS \\
\hline Lean body mass ( $\%$ of body weight) & $84.8(1.7)$ & $91.5(0.6)$ & $91.5(0.3)$ & $<0.05$ & $<0.05$ & NS \\
\hline Grip strength (\% of body weight) & $75.2(2.6)$ & $54.9(1.7)$ & $58.8(1.7)$ & $<0.05$ & NS & NS \\
\hline Leg strength ( $\%$ of body weight) & $318.1(15.3)$ & $347.5(26.7)$ & $389.0(65.4)$ & NS & $<0.05$ & $<0.05$ \\
\hline $\mathrm{VO}_{2} \operatorname{MAX}(\mathrm{ml} / \mathrm{kg} / \mathrm{min})$ & $40.2(1.0)$ & $47.8(0.9)$ & $50.1(0.8)$ & $<0.05$ & $<0.05$ & $<0.01$ \\
\hline
\end{tabular}

ANOVA, analysis of variance; NS, not significant.

until the subject was exhausted or could no longer maintain pedalling at $55 \mathrm{rpm}$. Respiratory and gas exchange parameters were measured every minute using a Grass Polygraph (model 7; Grass Inc., Quincy, USA), a parametric $\mathrm{O}_{2}$ analyser (Beckman OM-11; Beckman Instruments, Fullerton, CA, USA), and an infrared $\mathrm{CO}_{2}$ analyser (Beckman LB-2).

BLOOD AND URINE SAMPLES

Blood samples were withdrawn by venipuncture from the antecubital vein of the boxers before and after intensive training and 12 hours after a match. Twenty four hour urine specimens were obtained in the same period as the blood samples. Fresh void urine was collected within 90 minutes of a match.

The blood was allowed to clot at room temperature and centrifuged for 10 minutes to obtain serum. Serum AST and ALT activities were determined by the enzymic rate method $^{12}{ }^{13}$, albumin by the timed endpoint method, ${ }^{14}$ and creatinine by the modified Jaffe method $^{15}$ as adapted for the autoanalyser by Synchron CX systems (Beckman Instruments). Creative Kinase (CK) and CK-MB activity were measured by determining the rate of increase in $\mathrm{NADPH}^{16}$ and the immunoinhibition method ${ }^{17}$ respectively, using Granutest kits (E Merck, Darmstadt, Germany). LDH activity was determined by measuring $\mathrm{NADH}$ consumption using the reagent kits

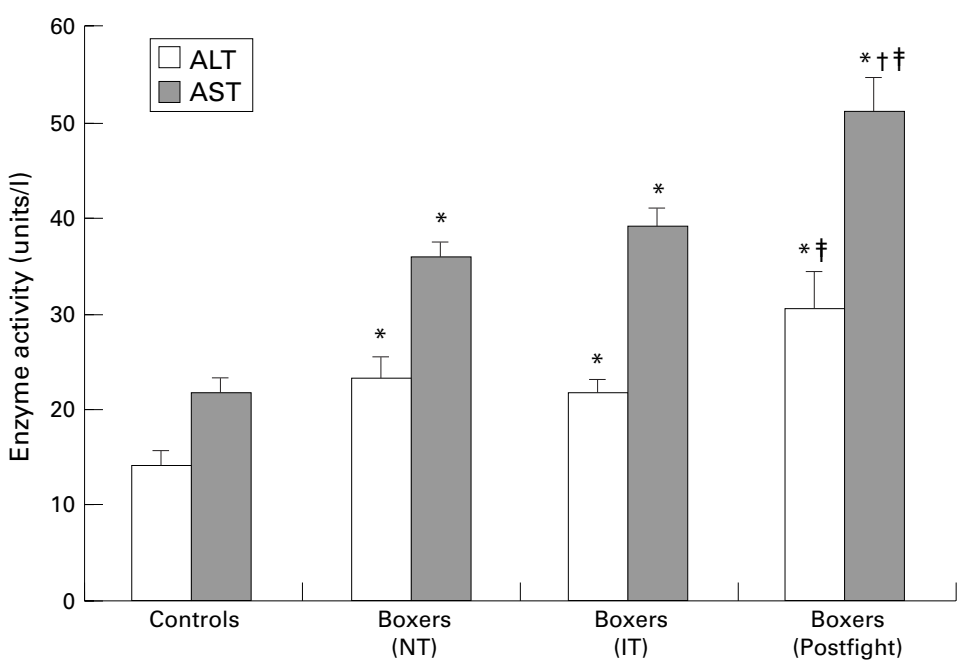

Figure 1 Alanine aminotransferase (ALT) and aspartate aminotransferase (AST) activities in controls and boxers during the period of normal training (NT), intensive training (IT), and after a fight. Values are means with error bars showing SEM. ${ }^{*} p<0.05$ compared with the control group; $t p<0.05$ compared with the period of normal training; $\ddagger p<0.05$ compared with the period of intensive training. from Sigma (St Louis, MO, USA). Physical properties of fresh void and 24 hour urine samples were determined for haemoglobinuria, myoglobinuria, ${ }^{18}$ and haematuria. Total protein concentration was quantified by the method of Coomassie brilliant blue dye binding. ${ }^{19}$ Microalbumin was measured by the immunoturbidimetric method ${ }^{20}$ using a commercial kit (Miles, United Kingdom).

In the sedentary controls, all physical fitness tests and sample collections were the same as for the boxers, but they were not involved in competition and did not perform any sports activities or physical exertion for at least one week before and during the experimental period.

\section{DATA ANALYSIS}

Statistical evaluation of significant difference within the group of Thai boxers was performed by Student's paired $t$ test, and between group differences were calculated by one way analysis of variance using the SPSS for Windows program. A difference was considered significant at a statistical probability of less than 0.05 .

\section{Results}

Table 1 shows the general physical characteristics of the subjects. The subjects in the two groups were in the same age range. However, body weight, height, percentage of body fat, and lean body mass of the sedentary controls were significantly higher than those of the boxers. When body weight was taken into account, percentage of lean body mass of the boxers was significantly higher than that of the controls. The physical characteristics of the boxers were not changed after intensive training. Also shown in table 1 is the physical fitness of the boxers during the period of normal and intensive training compared with that of the controls. The grip strength of the controls was significantly higher than that of the boxers during the normal training period. Although the grip strength of the boxers tended to increase after intensive training, a significant difference was not found. On the other hand, maximum oxygen uptake and leg strength of the boxers were higher than those of the controls, and further increments in both parameters were observed after intensive training.

It is evident from figs 1 and 2 that, even during the period of normal training, serum AST, ALT, CK, CK-MB, and LDH activities of the boxers were significantly higher than those of the controls. Figure 1 shows that intensive 


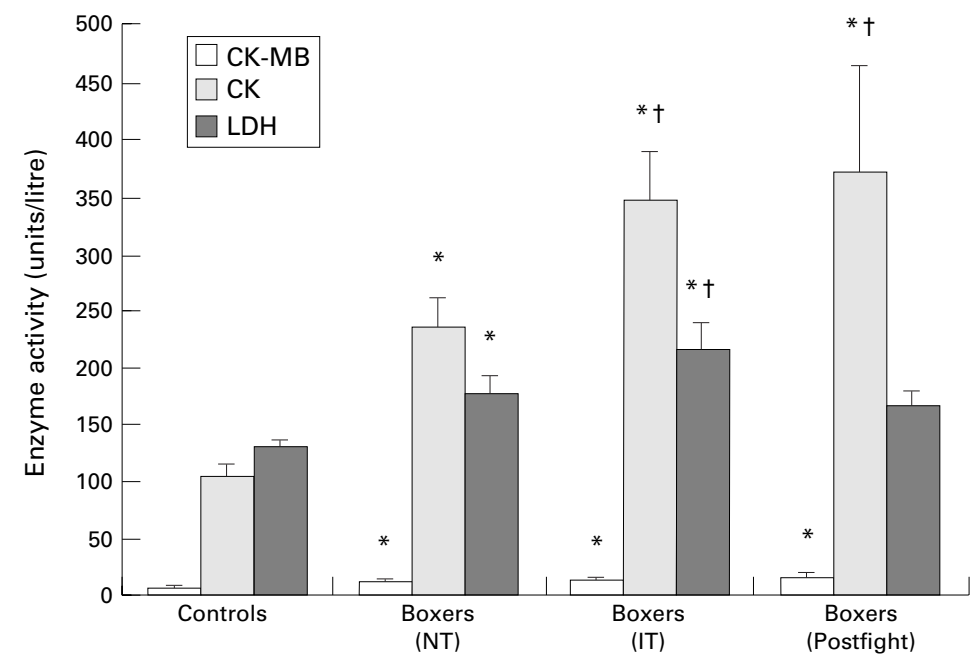

Figure 2 Creatine kinase (CK), $C K-M B$, and lactate dehydrogenase (LDH) activities in controls and boxers during the period of normal training (NT), intensive training (IT), and after a fight. Values are means with error bars showing SEM. ${ }^{{ }^{*}} p<0.05$ compared with the control group; $t p<0.05$ compared with the period of normal training.

training had no effect on the activities of serum AST and ALT, but increases in both aminotransferases were found after a boxing match. When compared with the control group, AST and ALT activities of the boxers after a fight were 2-2.5-fold higher. Figure 2 shows notable differences in the mean activities of CK, $\mathrm{CK}-\mathrm{MB}$, and $\mathrm{LDH}$ between the controls and boxers at all periods, except LDH after a fight. The activities of CK and LDH after intensive training and that of $\mathrm{CK}$ after a fight were greatly increased. As shown in table 2, the level of serum albumin of the boxers during normal and intensive training was significantly lower than that of the control group. However, this value was greatly increased after a fight and was then not significantly different from that of the controls.

Table 2 shows the mean values for creatinine concentration in serum and urine samples, packed cell volume, and creatinine clearance. Serum creatinine and packed cell volume in the two groups were comparable, and training in the boxers had virtually no effect on these parameters. However, urine creatinine in the boxers was considerably lower after a match leading to a significant decrease in creatinine clearance. The physical properties of all the urine samples were normal. Neither haematuria nor proteinuria was found. Thus urinary excretion of total protein or microalbumin in the boxers before and after competition was

Table 2 Blood and urine data, and creatinine clearance of boxers and controls. Values represent mean (SEM)

\begin{tabular}{lllll}
\hline & \multicolumn{3}{l}{ Boxers } \\
\cline { 3 - 5 } Parameter & Controls & $\begin{array}{l}\text { Normal } \\
\text { training }\end{array}$ & $\begin{array}{l}\text { Intensive } \\
\text { training }\end{array}$ & After match \\
\hline Packed cell volume (\%) & $45.8(0.7)$ & $43.9(1.0)$ & $42.8(0.8)$ & $42.8(1.5)$ \\
Serum albumin (g/l) & $44.9(1.0)$ & $40.8(0.7)^{\star}$ & $41.0(1.1)^{\star}$ & $45.4(0.9) \dagger$ \\
Protein urea $(\mathrm{mg} /$ day) & $43.8(9.1)$ & - & $29.6(3.1)$ & $32.4(10.6)$ \\
Microalbuminuria (mg/day) & $3.9(0.8)$ & - & $4.8(0.9)$ & $2.4(0.9)$ \\
Serum creatinine $(\mu \mathrm{mol} / \mathrm{l})$ & $87.4(2.2)$ & $89.8(3.8)$ & $88.9(4.5)$ & $86.1(3.2)$ \\
Urine creatinine $(\mathrm{mmol} /$ day) & $9.3(0.3)$ & $7.6(0.4)$ & $7.2(0.4)^{\star}$ & $4.8(0.8)^{\star} \dagger$ \\
Creatinine clearance $(\mathrm{ml} / \mathrm{min})$ & $84.1(4.6)$ & $87.5(6.5)$ & $78.5(3.7)$ & $54.7(9.6)^{\star} \dagger$ \\
\hline
\end{tabular}

${ }^{\star} \mathrm{p}<0.05$ compared with the control group.

$t \mathrm{p}<0.05$ compared with other periods of the boxer group. not changed and was not different from the control subjects (table 2).

\section{Discussion}

In this study, the age of the subjects in the two groups was similar, but body weight, height, lean body mass, and percentage body fat of the sedentary subjects were higher than those of the boxers. It is important to note that most of the Thai boxers in this study came from low socioeconomic backgrounds and their initial nutritional condition was poor. Although once in the training stable their nutrition was greatly improved, the period of replenishment may not have been long enough to restore their physical characteristics to normal or they had already reached puberty. Moreover, they trained regularly and intensively. This may explain why the boxers in this study are smaller than the sedentary controls of the same age.

Although the Thai boxers were anthropometrically inferior to the control subjects, their overall physical fitness was evidently better. This is not surprising since it is known that physical training, if sufficient, will improve fitness and performance. ${ }^{21}$ Noteworthy is the finding that the grip strength of the boxers was significantly less than that of the sedentary controls. This difference may be partly accounted for by body size, and hence lean body mass, and training. The usual training protocol for Thai boxers is aimed at improving strength, balance, endurance, and agility of the arm, trunk, and lower extremities and is not aimed at improving hand grip strength. The training puts more emphasis on the strength of the legs, which is reasonable since kicking and kneeing are predominant offensive strategies in Thai boxing. On the other hand, there is no training for hand grip strength because fists are rarely used during a fight, and gripping is not an important action in a sport in which boxing gloves are worn.

It is well known that LDH, AST, and CK and its isoenzymes are present in skeletal muscle, liver and red blood cells. ${ }^{22}$ In this study, the higher activities of these muscle enzymes in the boxers than in the sedentary controls could be accounted for by the training effect. After intensive training, serum $\mathrm{LDH}$ and $\mathrm{CK}$ activities of the boxers were further elevated to almost 2-fold and more than 3-fold the respective values in the sedentary controls. However, the concentration of CK-MB remained unchanged, and, after a boxing match, these muscle enzyme activities were not further increased. These data indicate that some skeletal muscle cell damage may have occurred during prefight training. This is not surprising since the training protocol during this period involves strenuous and prolonged target hitting with feet, knees, and elbows and dual fights with either trainers or other boxers in the same stable. All of these practices produce a high risk of injury. Indeed, accidental injury to various parts of the body during training occurred occasionally. There may be several factors responsible for the changes in serum enzyme activities during training, such as changes in muscle membrane permeability, ${ }^{23}$ possibly as 
the result of muscle glycogen depletion ${ }^{24}$ or lipid peroxidation of cell membrane, ${ }^{25} 26$ cellular damage induced by mechanical processes, ${ }^{27}$ haemodilution, or haemoconcentration. ${ }^{28}{ }^{29} \mathrm{It}$ is unlikely that the high concentrations of circulating muscle enzymes of the boxers in this study are due to haemoconcentration since the packed cell volume of the boxers was no different from that of the sedentary controls. In fact, there was a tendency for it to be lower-that is, haemodilution. Moreover, after a match the packed cell volume of the boxers was virtually not altered, indicating no changes in plasma volume. The increases in serum enzyme activities were therefore probably due to mechanical damage to the muscle cells, membrane lipid peroxidation resulting from the increased rate of oxygen consumption, or muscle glycogen depletion. In this study, serum ALT and AST activities were used as indicators of liver injury. Although these markers may not be specific to the liver, the activities of these enzymes in the blood have been used to evaluate hepatocellular damage in previous studies. ${ }^{22}{ }^{30}$ It has been shown that some well trained runners have ALT activities $20 \%$ above the upper limit of normal. ${ }^{30}$ The activities of ALT and AST of the Thai boxers were significantly higher than those of the sedentary controls. This may be attributed to the training effect. Further increases in these enzymes after competition suggest that damage to the liver may have occurred. However, since AST is also present in skeletal muscle ${ }^{31}$ and LDH activity showed no change after competition, it is more likely that muscle injury, rather than liver cell damage, accounts for the increase in AST. To ascertain whether Thai boxing matches cause hepatocyte damage requires further study using more specific markers such as glutathione S-transferase or cholinesterase.

To evaluate kidney function, urinalysis, including total protein, microalbumin, creatinine excretion, glomerular filtration rate estimated from creatinine clearance, physical properties of urine, haematuria, and myoglobinuria, was carried out. None of these parameters, except urine creatinine content during the prefight period, in the boxers were different from those in the sedentary controls (table 2). It is known that creatinine is mainly derived from muscle. The lower urine creatinine content in the boxers than the controls may be explained by the fact that the former were smaller and had less muscle or lean body mass. After competition there were no detectable changes in the urinary parameters studied, including haemoglobinuria, myoglobinuria, proteinuria, and haematuria. However, urine creatinine content and creatinine clearance were further decreased. Since creatinine clearance is an estimate of glomerular filtration rate, the results indicate that this function of the kidneys is decreased after a match. Changes in renal haemodynamics - for example, reduction in renal blood flow-may be responsible for the decrease in glomerular filtration rate. It is known that blood flow can be reduced by increases in sympathetic nervous activity, increased secretion of adrenaline and nor- adrenaline by adrenal glands, and increased plasma concentrations of angiotensin. ${ }^{32}$ These changes occur during exercise and fighting. ${ }^{33}$ In addition, direct physical injury to the kidneys or the lower urinary tract may be another cause of changes in renal function. ${ }^{34} 35$

The failure to detect haematuria in the Thai boxers after a match cannot be due to the dilution effect of a large urine volume because it was microscopically observed in the sediment after centrifugation. Furthermore, as most urine samples were hypertonic to plasma, it is unlikely that lysis of red blood cells occurred. The data therefore suggest that the deleterious effect of Thai boxing is insufficient to cause either massive renal haemodynamic changes leading to increases in glomerular filtration of erythrocytes or physical injury resulting in bleeding in the lower urinary tract as previously reported for other sports. ${ }^{7436}$

In conclusion, the training protocol for Thai boxers has virtually no deleterious effects on liver and renal function, but skeletal muscle cell damage is implicated. However, Thai boxing competition may cause muscle injuries without any obvious damage to the liver and kidneys. Nevertheless, both boxers and coaches should be aware of the possibility of injury, and appropriate coaching and training techniques that emphasise defensive strategies should be used to provide maximum protection of the vital organs. In addition, the use of protective pads that cover these essential organs, thorough medical examination, and the intake of adequate nutritional supplements such as essential water soluble vitamins and proteins is advised.

The authors thank the Sports Authorities of Thailand for financial support for this study. We are grateful to Dr Chaturaporn $\mathrm{Na}$ Nakorn and $\mathrm{Mr}$ Chaiyasit Leechanavanishpan (Division of Sports Science, Sports Authorities of Thailand) for the use of their laboratory for physical fitness measurements, and $\mathrm{Mr}$ Sthira Sthirasuta and Nun Sansanee Sthirasuta, the owner of the Sor-Pleonchit boxing stable, for allowing the boxers to participate in the study. Thanks are also extended to all staff and boxers at the Sor-Pleonchit boxing camp, and to Mrs Metta Pinthong and Mr Pisit Charnrungsi for technical assistance.

1 Noakes TD. Effect of exercise on serum enzyme activities in humans. Sports Med 1987;4:245-67.

2 Nagel D, Seiler D, Franz H, et al. Ultra-long-distance running and the liver. Int $\mathcal{F}$ Sports Med 1990;11:441-5.

3 Koutedakis Y, Raafat A, Sharp NC, et al. Serum enzyme activities in individuals with different levels of physical fitness. F Sports Med Phys Fitness 1993;33:252-7.

4 Lutoslawska G, Sendecki W. Plasma biochemical variables in response to $42-\mathrm{km}$ kayak and canoe races. F Sports Med Phys Fitness 1990;30:406-11.

5 Freund BJ, Shizuru EM, Hashiro GM, et al. Hormonal, electrolyte, and renal responses to exercise are intensity dependent. F Appl Physiol 1991;70:900-6.

6 Kachadorian WA, Johnson RE. Renal responses to various rates of exercise. F Appl Physiol 1970;28:748-52.

7 Castenfors J. Renal function during prolonged exercise. Ann N Y Acad Sci 1977;301:151-9.

8 Poortmans JR. Postexercise proteinuria in humans. $f A M A$ 1985;253:236-40.

9 Ross RJ, Casson IR, Seigel O, et al. Boxing injuries: neurologic, radiologic and neuropsychologic evaluation. Clin Sports Med 1987;6:41-51.

10 Ross RJ, Cole M, Thompson JS, et al. Boxers: computed tomography, EEG, and neurologic evaluation. $\mathcal{f} A M A$ 1983;249:211-13.

11 Siri WE. The gross composition of the body. In: Lawrence $\mathrm{JH}$, Tobias CA, eds. Advances in biological and medical physics. New York: Academic Press, 1956:239-80.

2 Henry RJ. Clinical chemistry: principles and technics. 2nd ed. New York: Harper \& Row, 1974.

13 Rodgerson DO. Development of a method for aspartate aminotransferase activity measurement by the subcommittee on enzymes, AACC: a progress report. In: Proceedings of the Second International Symposium on Clinical Enzymology. the Second International Symposium on Clinical Enzymology. istry, 1976 . 
14 Pinnell AE, Northam BE. New automated dye-binding method for serum albumin determination with bromocresol purple. Clin Chem 1978;24:80-6.

15 Vasiliades J. Reaction of alkaline sodium picrate with creatinine. I. Kinetics and mechanism of formation of the monocreatinine picric acid complex. Clin Chem 1978;22:166471 .

16 Deutsche Gesellschaft fur Klinische Chemie. Standard method for the determination of creatine kinase activity. $\mathcal{F}$ Clin Chem Clin Biochem 1977;15:249-60.

17 Wurzburg U, Hennrich N, Orth HD, et al. Quantitative determination of creatine kinase isoenzyme catalytic concentrations in serum using immunological methods. $\mathcal{F}$ Clin Chem Clin Biochem 1977;15:131-7.

18 Beau F. A method for hemoglobin in serum and urine. Am $\mathcal{F}$ Clin Pathol 1962;38:111-2.

19 Peters T Jr, Biamonte GT, Doumas BT. Protein (total protein) in serum, urine, and cerebrospinal fluid; albumin in serum. In: Faulkner WR, Meites S, eds. Selected methods of serum. In: Faulkner WR, Meites S, eds. Selected methods of
clinical chemistry, vol. 9. Washington DC: American Association of Clinical Chemistry, 1982.

20 Fudenberg HH, Stites DP, Caldwell JL, et al (eds). Basic and clinical immunology. 3rd ed. Los Altos: Lange Medical Pubishing, 1980

21 Astrand PO, Rodahl K. Textbook of work physiology. 1st ed. New York: McGraw-Hill, 1970.

22 Ward KM. Chemistry of exercise. In: Anderson SC, Cockayne S, eds. Clinical chemistry: concept and applications. 1st ed. Philadelphia: WB Saunders Company, 1993:63451.

23 Haralambie G. Neuromuscular irritability and serum creatine phosphaate kinase in athletes in training. Int $\mathcal{F}$ Rehabil Res 1973;31:279-88.
24 Bricknell OL, Daries PS, Opie LH. A relationship between adenosine triphosphate, glycolysis and ischaemic contracture in the isolated rat heart. $f \mathrm{Mol}$ Cell Cardiol 1981;13:941-5

25 Kanter MM, Kaminsky LA, Laham-Saeger J, et al. Serum enzyme levels and lipid peroxidation in ultra marathon runners. Annals of Sports Medicine 1986;3:39-41.

26 Jenkins RR. Free radical chemistry. Relation to exercise. Sports Med 1988;5:156-70.

27 Friden J, Sjostrom M, Ekblom B. Myofibrillar damage following intense eccentric exercise in man. Int $\mathcal{F}$ Sports Med 1983;4:170-6.

28 Beaumont WV, Strand JC, Petrofsky JS, et al. Changes in total plasma content of electrolytes and proteins with maximal exercise. J Appl Physiol 1973;34:102-6.

29 Hunter JB, Critz JB. Effect of training on plasma enzyme levels in man. F Appl Physiol 1971;31:20-3.

30 Apple FS, McGue MK. Serum enzyme changes during marathon training. Am f Clin Pathol 1983;79:716-19.

31 Braunwald E. Harrison's principles of internal medicine 2. 11 th ed. New York: McGraw-Hill, 1987.

32 Lamb DR. Physiology of exercise. 2nd ed. New York: MacMillan Publishing, 1984.

33 Cianflocco AJ. Renal complications of exercise. Clin Sports Med 1992;11:437-51.

34 Alyea EP, Parish HH. Renal response to exercise: urinary findings. FAMA 1958;167:807-13.

35 Streeton JA. Traumatic haemoglobinuria caused by karate exercises. Lancet 1967;2:191-2.

36 Blacklock NJ. Bladder trauma in the long-distance runner. Am f Sports Med 1979;7:239-41.

\section{British Fournal of Sports Medicine http://www.bjsportmed.com}

Visitors to the world wide web can now access the British fournal of Sports Medicine either through the BMJ Publishing Group's home page (http://www.bmjpg.com) or directly by using its individual URL (http://www.bjsportmed.com). There they will find the following:

- Current contents list for the journal

- Contents lists of previous issues

- Members of the editorial board

- Information for subscribers

- Instructions for authors

- Details of reprint services.

A hotlink gives access to:

- BMJ Publishing Group home page

- British Medical Association web site

- Online books catalogue

- BMJ Publishing Group books.

The web site is at a preliminary stage and there are plans to develop it into a more sophisticated site. Suggestions from visitors about features they would like to see are welcomed. They can be left via the opening page of the BMJ Publishing Group site or, alternatively, via the journal page, through "about this site". 